\title{
TESTING OF ADHESIVE SPRAY PAINTING WITH ROBOT
}

\author{
Marek Sukop, Mikuláš Hajduk, Ján Semjon, Jozef Varga, \\ Rudolf Jánoš, Marek Vagaš, Martin Bezák, Ivan Virgala
}

Professional paper

This article aims at setting appropriate parameters for robotic spraying of adhesives used in industry. The robot ABB IRB 1600 was used in a nonexplosive environment. The adhesive was dispensed from pressure sweat and applied by a Krautzberger RA5 spray head. The article describes a detailed diagram for automatic connection of a painting gun. The results of the individual tests are shown in the tables and the dependencies of the individual parameters are described in the graphs. Depending on the amount of spray applied, the best samples are evaluated according to the adhesive manufacturer's recommendations.

Keywords: adhesive; painting gun; pressure pot; robot

Ispitivanje bojenja mlazom adhezivnog sredstva nanesenog robotom

Cilj je ovoga rada određivanje odgovarajućih parametara za raspršivanje adheziva korištenih u industriji uz primjenu robota. Korišten je robot ABB IRB 1600 u neeksplozivnom okruženju. Adheziv se oslobađao iz tlačne posude i nanosio raspršivačem Krautzberger RA5. U radu se daje detaljan opis dijagrama za automatsko spajanje pištolja za bojenje. Rezultati pojedinačnih testova dani su u tablicama, a ovisnosti pojedinih parametara prikazane su u grafikonima. Ovisno o količini nanesenog mlaza, najbolji uzorci su ocijenjeni u skladu s preporukama proizvođača adheziva.

Ključne riječi: adheziv; pištolj za bojenje; robot; tlačna posuda

\section{Introduction}

Spray painting is primarily used in industry, especially automotive. The uniformity of paint thickness on a product can strongly influence its quality, which is typically determined by the robot painting path. Robot path planning with uniform material distribution remains a challenging research topic in the spraying processes. There are two path planning methods by robot: manual and automatic. Manual robot path planning methods (teaching methods) are based on manufacturing engineers' experience and knowledge of production facilities, equipment, their capabilities, processes, and tools. A manufacturing engineer has to carry out extensive tests on a work cell to improve a painting path in order to obtain a good spraying distribution. This process is complex and very time-consuming. The results vary based on each manufacturing engineer's skills. Path planning usually requires the engineers to use a trial-anderror approach to find a good robot spraying path for painting processes. The generated path is usually operator-dependent and error-prone. It is even harder for engineers to figure out better paths when some performance criteria have to be considered [1,2].

This article describes testing of adhesive spray painting and dependence between speed of robot, pressure of pressure pot, pressure on painting gun, nozzle lift on the gun and distance between painting gun needle and spraying area. Sprayed samples were evaluated and selected to the best with optimal weight. ABB IRB 1600, the HVLP painting gun Krautzberger RA5 HV3, pressure pot (PP) and adhesive with viscosity $3.500 \mathrm{mPa} \cdot \mathrm{s}$ were used for the tests. During testing only round type of spraying was used.

\section{Main parameters of spraying adhesive}

\begin{tabular}{ll}
\hline Base: & Water borne polyurethane dispersion \\
\hline Solid content: & Approx. $45 \%$ \\
\hline Viscosity at $20{ }^{\circ} \mathrm{C}:$ & $\begin{array}{l}\text { Approx. } 3500 \mathrm{mPa} \cdot \mathrm{s} \\
\text { (Brookfield RVT, } \mathrm{Sp} 3,20 \mathrm{RPM})\end{array}$ \\
\hline Density at $20{ }^{\circ} \mathrm{C}:$ & Approx. $1.05 \mathrm{gr} / \mathrm{cm}^{3}$ \\
\hline pH: & Approx. 7.5 \\
\hline Consumption: & $\begin{array}{l}\text { Approx. } 80 \div 120 \mathrm{~g} / \mathrm{m}^{2} \text { wet depending } \\
\text { on the substrate }\end{array}$ \\
\hline Activation temperature: & $55 \div 80^{\circ} \mathrm{C}$ \\
\hline Drying: & $\begin{array}{l}\text { At ambient temperature }\left(20{ }^{\circ} \mathrm{C}\right): \\
20 \div 60 \text { minutes }\end{array}$ \\
\hline In drying tunnel: & $\begin{array}{l}\text { Hot air at } 50 ~ \\
\text { minutes. It is very important that the } \\
\text { temperature of the adhesive film not } \\
\text { exceed } 50{ }^{\circ} \mathrm{C} .\end{array}$ \\
\hline Material and product & \\
\hline Temperature: & $15 \div 25^{\circ} \mathrm{C}$ \\
\hline Pot life: & $\begin{array}{l}\text { Approx. } 8 \text { hours at } 20{ }^{\circ} \mathrm{C} \text { or } 4 \text { hours at } \\
\end{array}$ \\
\hline Dilution and cleaning: & $\begin{array}{l}\text { Fresh water while the adhesive is } \\
\text { fresh. }\end{array}$ \\
\hline
\end{tabular}

This adhesive is heat-activated, two-component dispersion adhesive for the bonding of PVC-foil, carpet and textile to moulded body parts with ABS, fibre, wood pulp, etc. It is used in the production of car roofs, door trims, parcel shelves, pillar trims etc. For instance in case of PP is needed a pre-treatment by flame is needed, in order to increase the superficial tension to $38 \div 40 \mathrm{mN} / \mathrm{m}$. The adhesive has very good spraying properties, fast drying and after cross-linking, excellent water and heat resistance. The surfaces to bind must be clean, dry, without grease, wax or demoulding agents. The mixture of the adhesive with hardener must be done with a mechanical stirrer at average rotational speed max. 400 rpm, stirring during 8 to 10 minutes until homogeneous colour $[9,11]$. 
The adhesive mixture is applied with spray equipment. Best results are met with special equipment for aqueous products as HVLP type, with nozzles of 1.5 to 1.8. Equipment, container, hoses, etc. which come in contact with adhesive, must be of corrosion-resistant material (as stainless steel $\mathrm{V} 4 \mathrm{a} / 1.451$ or plastics as polyethylene, polypropylene or Teflon, to avoid coagulation. Any contact with non-ferrous metals, like hoses, sealing, rings, filter bodies and similar must be avoided in any case $[8,10]$.

When the adhesive film is completely dry, bonding is possible by means of heat reactivation. The temperature of the adhesive joint depends on the material and should be between $55 \div 80{ }^{\circ} \mathrm{C}$. A wet coating weight of approx. $100 \div 120 \mathrm{~g} / \mathrm{m}^{2}$ is applied on the substrate depending on the porosity of the materials $[6,7]$.

Adhesive must be completely dry before laminating. During the drying process the humidity in the drying channel increases very fast. The excessive moisture content must be reduced either by fresh air supply or by drying out physically. The maximum temperature in the drying channel is $50{ }^{\circ} \mathrm{C}$. In these conditions the drying time is usually $10 \div 15$ minutes. The drying time can be reduced when very dry air (relative humidity between 5 and $10 \%$ ) is used and the air circulation speed is increased to $2 \div 4 \mathrm{~m} /$ second [11].

The heat reactivation is only available within a period of approx. 8 hours after adding the hardener at $20{ }^{\circ} \mathrm{C}$. Higher temperatures decrease the processing time to 4 hours at $30{ }^{\circ} \mathrm{C}$, so we recommend not exceeding this time. If the adhesive is applied on both parts, on the carrier material as well as on the laminate, the open time for the carrier material is 4 hours and for the laminate 12 hours. These values are only valid for an application temperature of $25^{\circ} \mathrm{C}[4,5]$.

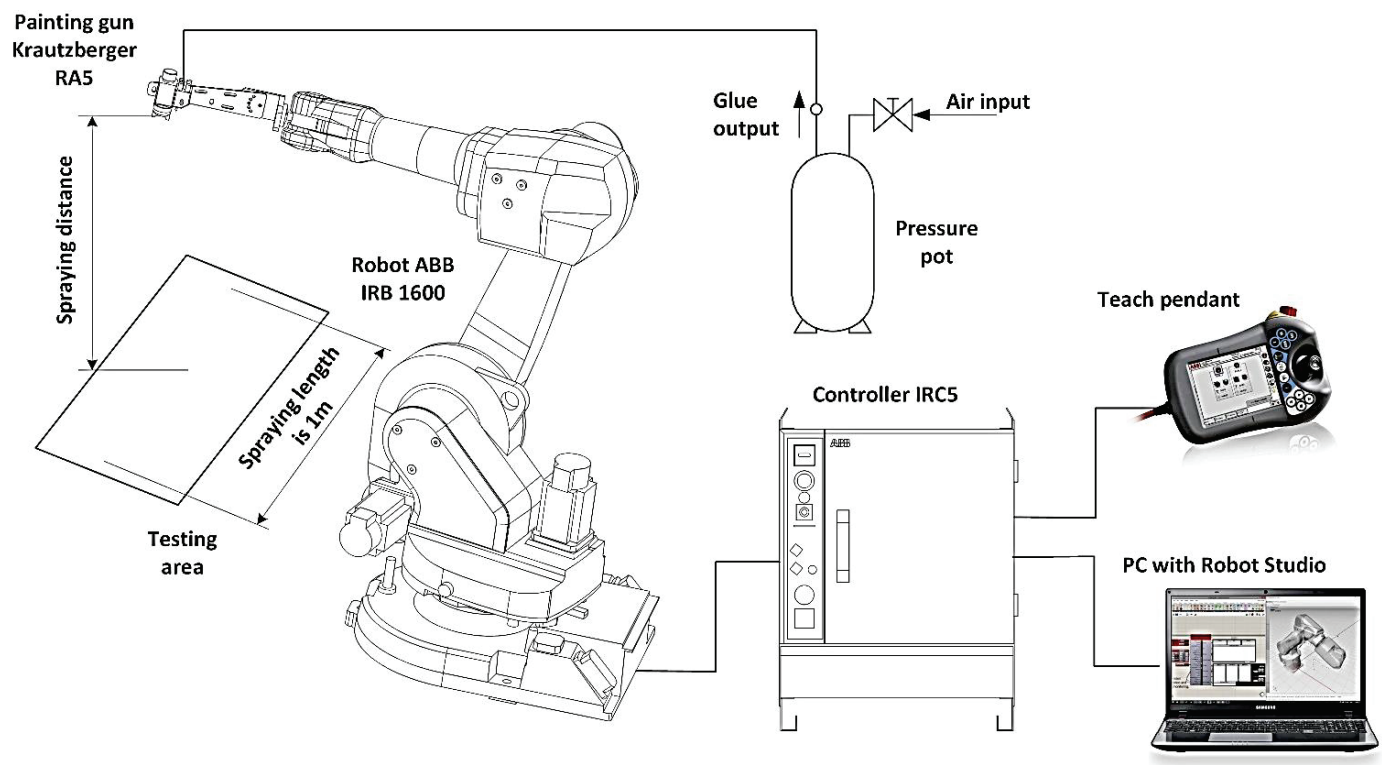

Figure 1 Assembly of robot spraying system

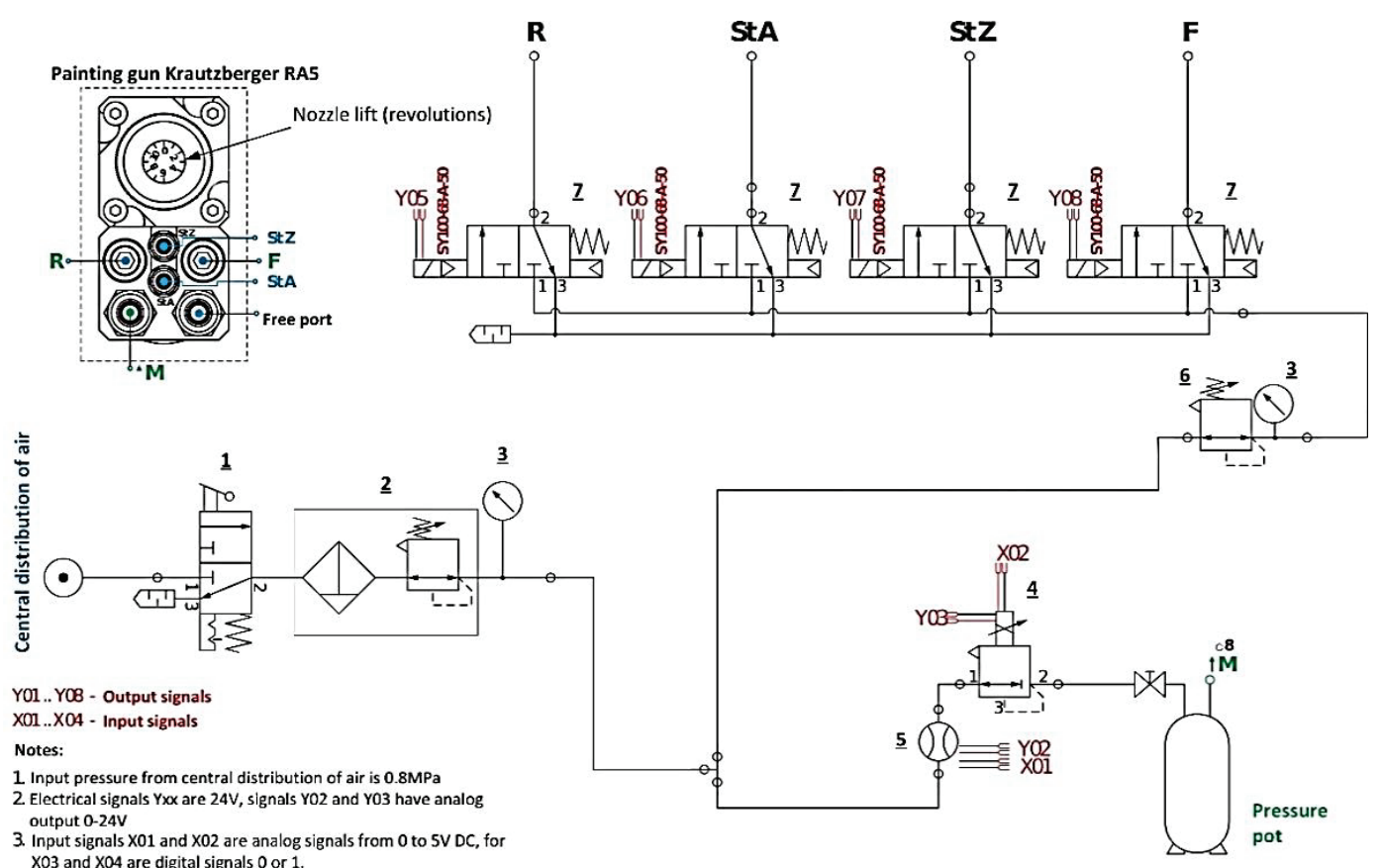

Figure 2 Connection diagram for spraying system 


\section{Assembly of robot spraying system}

This system consists of robot ABB IRB 1600 type with controller IRC5, pressure pot with adhesive and painting gun RA5 HV3 from Krautzberger company, see Fig. $1[1,12]$.

Connection diagram for spraying system is shown in Fig. 2. For our testing was used only round jet - air connected to round port (R), port StA for switching adhesive and port $\mathrm{M}$ for adhesive application.

Connection diagram shown in Fig. 2 consists of [13, 14]:

1. Pressure relief $3 / 2$ valve, G1/2"

2. Filter regulator, $\mathrm{G} 1 / 2^{\prime \prime}$

3. Pressure gauge

4. Electro-pneumatic regulator

5. Digital flow switch for air

6. Modular style regulator

7. $3 / 2$ port solenoid valve

$\mathrm{R}-$ Round jet

$\mathrm{F}-$ Flat jet

StA - Open adhesive

StZ - Close adhesive

$\mathrm{M}$ - Input adhesive

\section{$4 \quad$ Testing adhesive spraying with robot}

In all tests adhesive is sprayed linearly at a distance from the spraying area, and with total length of $1 \mathrm{~m}$. Only round jet was used for these tests. For all cases was primarily used weight ratio depending on speed of the robot, pressure at pressure pot, air pressure at painting gun and revolutions on gun. Maximum speed of robot was $2000 \mathrm{~mm} / \mathrm{s}[2,3]$.

In the tables are shown samples with settings of main parameters and dependencies of parameters are shown on charts.

\subsection{Spraying at distance of $10 \mathrm{~cm}$}

Table 1 Setting parameters for spraying at a distance of $10 \mathrm{~cm}$

\begin{tabular}{|c|c|c|c|c|c|c|c|}
\hline Sample & 1 & 2 & 3 & 4 & 5 & 6 & 7 \\
\hline Pressure pot (bar) & 2 & 2 & 2 & 2 & 2 & 2 & 1.5 \\
\hline $\begin{array}{l}\text { Gun air pressure } \\
\text { R-port (bar) }\end{array}$ & 3 & 3 & 2 & 3 & 3 & 3 & 3 \\
\hline Width of jet $(\mathrm{cm})$ & \multicolumn{7}{|c|}{4} \\
\hline $\begin{array}{l}\text { Revolutions on } \\
\text { gun (set adhesive } \\
\text { volume) }\end{array}$ & 5 & 5 & 1 & 5 & 5 & 5 & 5 \\
\hline $\begin{array}{l}\text { Speed of robot } \\
(\%)\end{array}$ & 75 & 50 & 25 & 40 & 30 & 20 & 25 \\
\hline $\begin{array}{l}\text { Weight of } \\
\text { adhesive }(\mathrm{g} / \mathrm{m})\end{array}$ & 3.7 & 5.5 & 5.6 & 6.8 & 9 & 13.75 & 13.9 \\
\hline $\begin{array}{l}\text { Weight of } \\
\text { adhesive }\left(\mathrm{g} / \mathrm{m}^{2}\right) \\
\text { (Ideal weight of } \\
\text { adhesive is } 100 \div \\
\left.120 \mathrm{~g} / \mathrm{m}^{2}\right)\end{array}$ & 93 & 138 & 140 & 170 & 225 & 344 & 348 \\
\hline
\end{tabular}

At first case, the adhesive was sprayed at a distance of $10 \mathrm{~cm}$ from the spraying area. Pressure at pressure pot was in the range between 1.5 and 2 bar. The pressure in painting gun for round spraying was set from 2 to 3 bars and the nozzle lift was from 1 to 5 revolutions, Tab. 1.

Legend in Fig. 3 chart is the same for all charts.
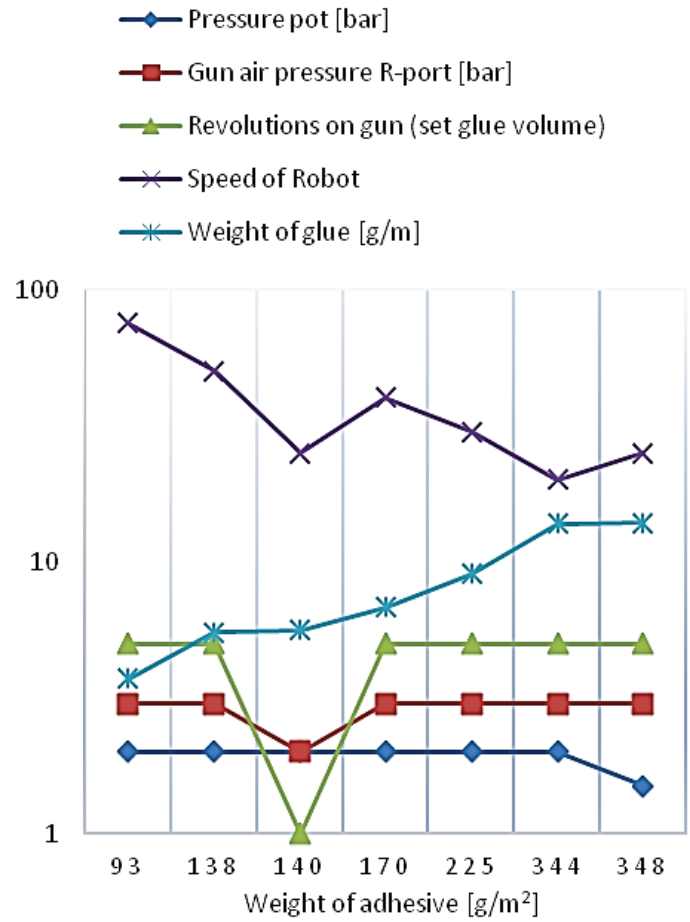

Figure 3 Dependent parameters for spraying at a distance of $10 \mathrm{~cm}$

\subsection{Spraying at a distance of $30 \mathrm{~cm}$}

At second case, the adhesive was sprayed at a distance of $30 \mathrm{~cm}$ from the spraying area. Pressure at pressure pot was 2 bars. The pressure at gun for round spraying was set from 2 to 3 bars and nozzle lift was from 2 to 6 revolutions. These parameters are shown in Tab. 2 . The fields marked in yellow show the best results of spraying.

Table 2 Setting parameters for spraying at a distance of $30 \mathrm{~cm}$

\begin{tabular}{|c|c|c|c|c|c|}
\hline Sample & 1 & 2 & 3 & 4 & 5 \\
\hline Pressure pot (bar) & 2 & 2 & 2 & 2 & 2 \\
\hline $\begin{array}{l}\text { Gun air pressure R- } \\
\text { port (bar) }\end{array}$ & 2 & 2 & 3 & 3 & 3 \\
\hline Width of jet $(\mathrm{cm})$ & \multicolumn{5}{|c|}{8} \\
\hline $\begin{array}{l}\text { Revolutions on gun } \\
\text { (set adhesive } \\
\text { volume) }\end{array}$ & 2 & 4 & 4 & 5 & 6 \\
\hline Speed of Robot (\%) & 25 & 25 & 25 & 25 & 25 \\
\hline $\begin{array}{l}\text { Weight of adhesive } \\
(\mathrm{g} / \mathrm{m})\end{array}$ & 5.2 & 6 & 7.9 & 8.5 & 9.3 \\
\hline $\begin{array}{l}\text { Weight of } \\
\text { adhesive }\left(\mathrm{g} / \mathrm{m}^{2}\right) \\
\text { (Ideal weight of } \\
\text { adhesive is } 100 \div \\
120 \mathrm{~g} / \mathrm{m}^{2} \text { ) }\end{array}$ & 65 & 98 & 99 & 106 & 116 \\
\hline
\end{tabular}

\subsection{Spraying at distance of $50 \mathrm{~cm}$}

In the third case, the adhesive was sprayed at a distance of $50 \mathrm{~cm}$ from the spraying area. Pressure at pressure pot was in the range between 2 and 4.6 bars. The pressure at gun for round spraying was set from 2.5 to 3 bars and lift the nozzle was 5 revolutions, Tab. 3 . 


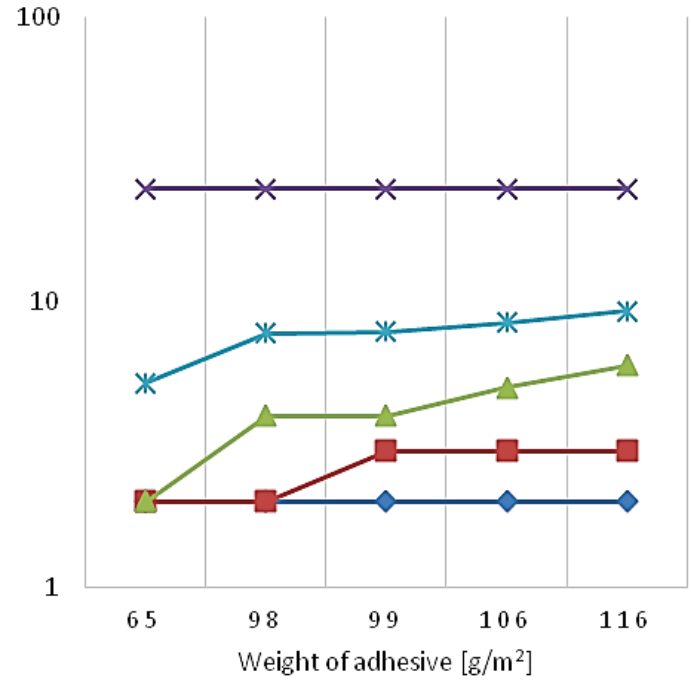

Figure 4 Dependent parameters for spraying at a distance of $30 \mathrm{~cm}$

Table 3 Setting parameters for spraying at a distance of $50 \mathrm{~cm}$

\begin{tabular}{|c|c|c|c|c|c|c|c|c|}
\hline Sample & 1 & 2 & 3 & 4 & 5 & 6 & 7 & 8 \\
\hline $\begin{array}{l}\text { Pressure pot } \\
\text { (bar) }\end{array}$ & 3.2 & 2 & 3.2 & 3.2 & 4.6 & 2 & 4.6 & 4.6 \\
\hline $\begin{array}{l}\text { Gun air } \\
\text { pressure R- } \\
\text { port (bar) }\end{array}$ & 3 & 3 & 3 & 2.5 & 2.5 & 3 & 2.5 & 2.5 \\
\hline $\begin{array}{l}\text { Width of jet } \\
(\mathrm{cm})\end{array}$ & \multicolumn{8}{|c|}{12} \\
\hline $\begin{array}{l}\text { Revolutions } \\
\text { on gun (set } \\
\text { adhesive } \\
\text { volume) }\end{array}$ & 5 & 5 & 5 & 5 & 5 & 5 & 5 & 5 \\
\hline $\begin{array}{l}\text { Speed of } \\
\text { Robot (\%) }\end{array}$ & 40 & 50 & 50 & 25 & 50 & 25 & 40 & 25 \\
\hline $\begin{array}{l}\text { Weight of } \\
\text { adhesive } \\
(\mathrm{g} / \mathrm{m})\end{array}$ & 5.2 & 5.5 & 7.2 & 8.2 & 13.4 & 15.5 & 15.5 & 18.1 \\
\hline $\begin{array}{l}\text { Weight of } \\
\text { adhesive } \\
\left(\mathrm{g} / \mathrm{m}^{2}\right) \text { (Ideal } \\
\text { weight of } \\
\text { adhesive is } \\
100 \div 120 \\
\left.\mathrm{~g} / \mathrm{m}^{2}\right)\end{array}$ & 43 & 46 & 60 & 68 & 111 & 129 & 129 & 151 \\
\hline
\end{tabular}

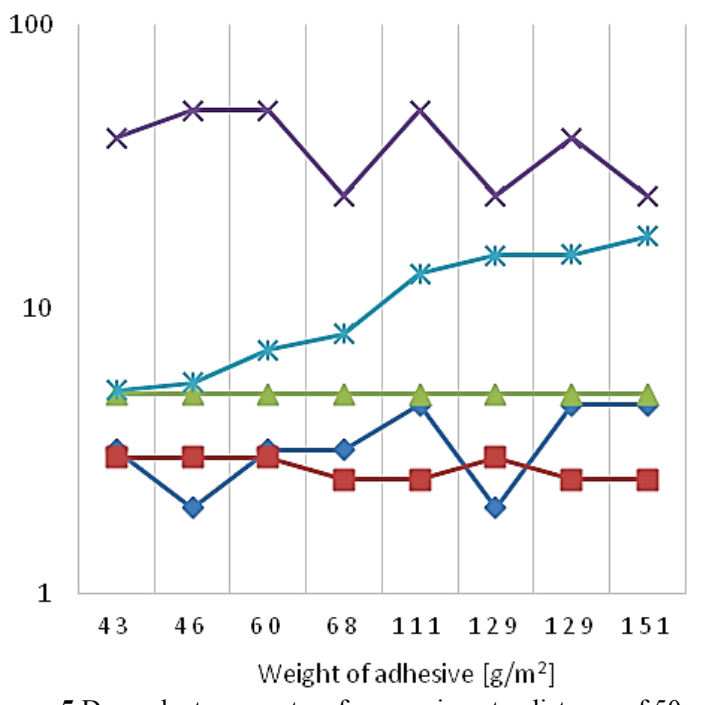

Figure 5 Dependent parameters for spraying at a distance of $50 \mathrm{~cm}$
Best results are in the 5, 6 and 7 samples. These samples are marked yellow in Tab. 3. Dependent parameters are shown in Fig. 5.

Width of jet is shown on a sample that is described in chapter 4 .

\section{Evaluations of adhesive spraying samples}

In testing of adhesive spraying at a distance of $10 \mathrm{~cm}$ from the spraying area, the best results were obtained from samples 1 and 2. Settings of these samples are closest to the recommended weight of adhesive sprayed per $\mathrm{m}^{2}$. The obtained samples are shown in Fig. 6 .

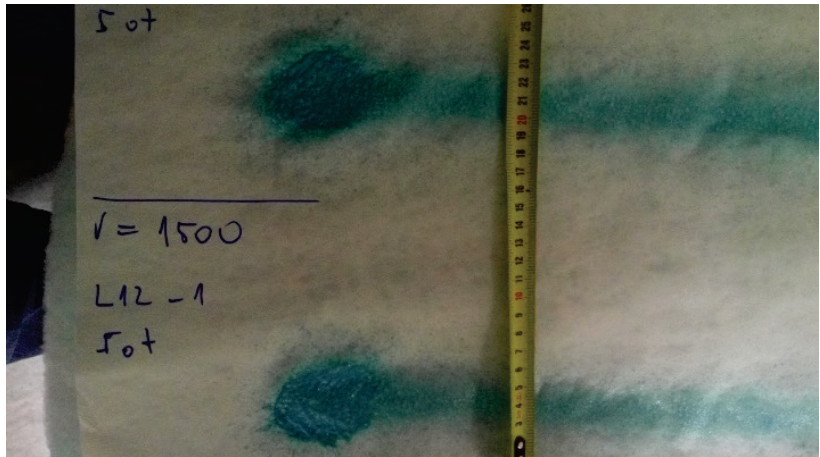

Figure 6 Sample 1 and 2 from the adhesive spraying at a distance $10 \mathrm{~cm}$

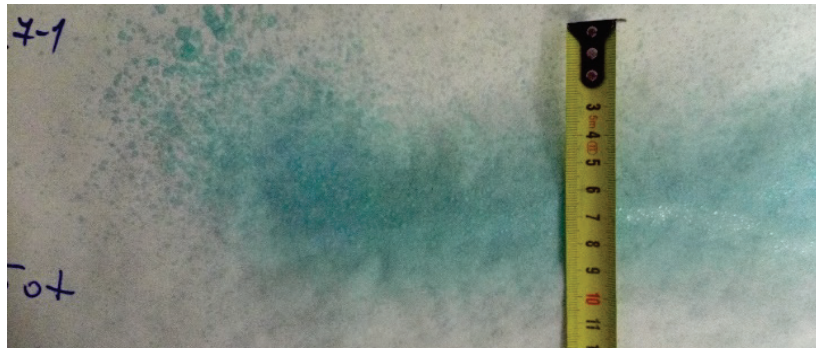

Figure 7 Sample 4 from the adhesive spraying at a distance of $30 \mathrm{~cm}$

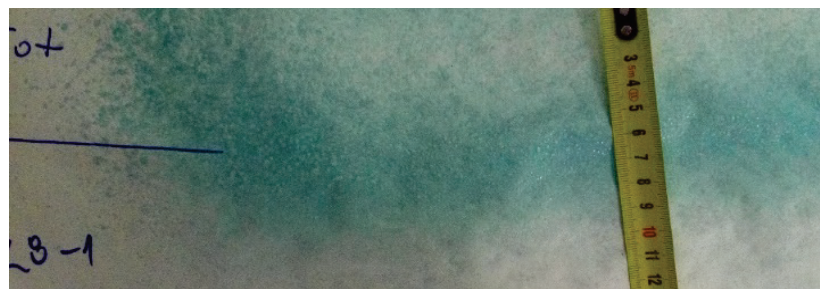

Figure 8 Sample 5 from the adhesive spraying at a distance of $30 \mathrm{~cm}$

In testing of the adhesive spraying at a distance of 30 $\mathrm{cm}$ from the spraying area, the best results were obtained from samples 4 and 5. Settings of these samples were closest to the recommended weight of adhesive sprayed per $\mathrm{m}^{2}$. The obtained samples are shown in Fig. 7 and Fig. 8.

In testing of adhesive spraying at a distance of $50 \mathrm{~cm}$ from the spraying area, the best results were obtained from the samples 5,6 and 7. Settings of these samples were closest to the recommended weight of adhesive sprayed per $\mathrm{m}^{2}$. The obtained samples are shown in Fig. 9, Fig. 10 and Fig. 11. The gaps between the adhesives are due to a trajectory that copies the shape of the door. 

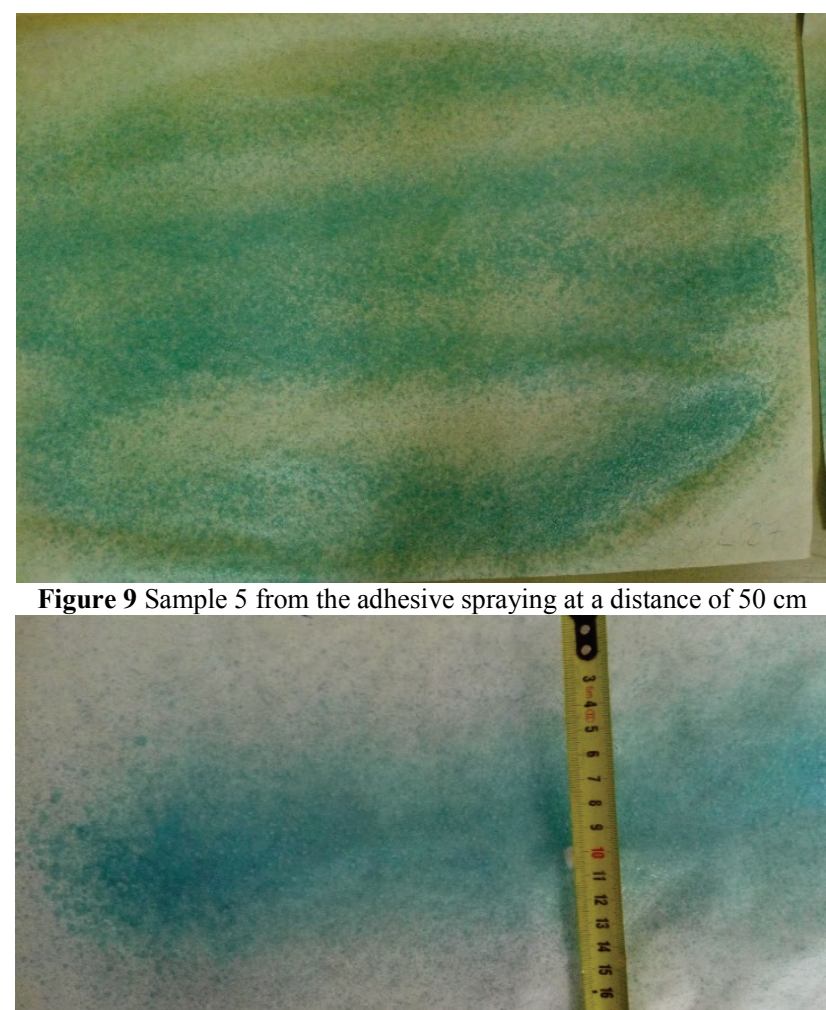

Figure 10 Sample 6 from the adhesive spraying at a distance of $50 \mathrm{~cm}$

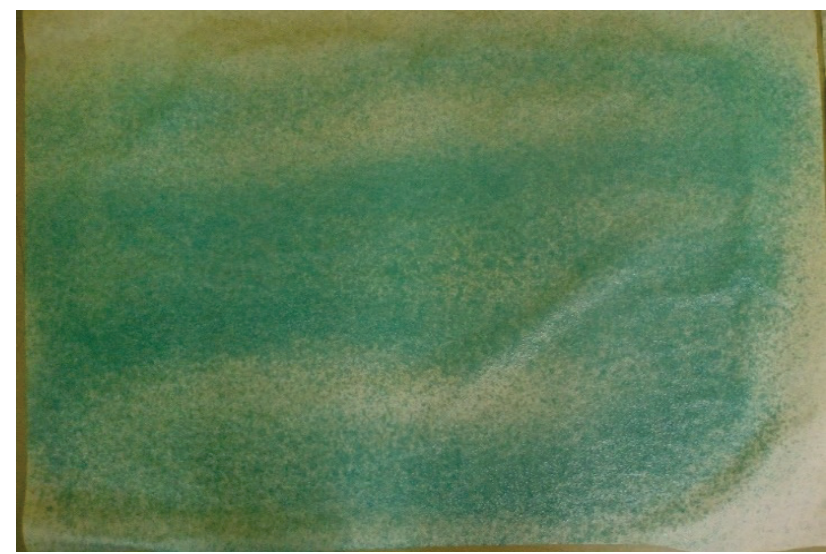

Figure 11 Sample 7 from the adhesive spraying at a distance of $50 \mathrm{~cm}$

\section{Conclusion}

This adhesive is used automotive. Currently, the adhesive is applied manually, but it is planned to automate the process. The aim of the adhesive spray painting testing from different distances from the spraying area was to determine appropriate parameters for robot speed, setting of pressure at pressure pot, setting of pressure and the sizing of nozzle lift (revolutions) at the painting gun. From testing samples representative samples were chosen with the weight of the sprayed adhesive which is closest to the recommended value of adhesive manufacturer. These settings of the parameters can be applied to the robotic spraying in various industries.

\section{Acknowledgements}

This contribution is the result of the project implementation: Research modules for intelligent robotic systems (ITMS: 26220220141), activity 2.2, supported by the Research \& Development operational Program funded by the ERDF and project 059TUKE-4-2014 Rozvoj kvality života, tvorivosti a motoriky hendikepovaných a starších osôb s podporou robotických zariadení.

This publication is the result of the project implementation: Research modules for intelligent robotic systems (ITMS: 26220220141), activity 1.2 supported by the Research \& Development Operational Program funded by the ERDF.

The authors would like to thank to Slovak Grant Agency - project VEGA 1/0872/16 financed by the Slovak Ministry of Education.

\section{References}

[1] Neto, P.; Mendes, N. Direct off-line robot programming via a common CAD package. // Robotics and Autonomous Systems. 61, 8(2013), pp. 896-910. https://doi.org/10.1016/j.robot.2013.02.005

[2] Hegels, D.; Wiederkehr, T.; Müller, H. Simulation based iterative post-optimization of paths of robot guided thermal spraying. // Robotics and Computer-Integrated Manufacturing. 35, (2015), pp. 1-15. https://doi.org/10.1016/j.rcim.2015.02.002

[3] Conner, D. C.; Greenfield, A. L.; Atkar, P.; Rizzi, A.; Choset, H. Paint deposition modeling for trajectory planning on automotive surfaces. // IEEE Transactions on Automation Science and Engineering. 2, 4(2005), pp. 381392. https://doi.org/10.1109/TASE.2005.851631

[4] Świć, A; Taranenko, W. Adaptive control of machining accuracy of axial-symmetrical low-rigidity parts in elasticdeformable state. // Eksploatacja i Niezawodnosc Maintenance and Reliability. 14, 3(2012), pp. 215-221.

[5] Božek, P.; Ivandić, Ž.; Lozhkin, A.; Lyalin, V.; Tarasov, V. Solutions to the characteristic equation for industrial robot's elliptic trajectories. // Tehnicki Vjesnik-Technical Gazette. 23, 4(2016), pp. 1017-1023. https://doi.org/10.17559/TV-20150114112458

[6] Lehocká, D.; Hlavatý, I.; Hloch, S.; Rationalization of material flow in production of semitrailer frame for automotive industry. // Tehnicki Vjesnik-Technical Gazette. 23, 4(2016), pp. 1215-1220. https://doi.org/10.17559/TV-20131113100109

[7] Iqbal, J.; Islam, R. U.; Abbas, S. Z.; Khan, A. A.; Ajwad, S. A. Automating industrial tasks through mechatronic systems - A review of robotics in industrial perspective. // Tehnicki Vjesnik-Technical Gazette. 23, 3(2016), pp. 917924. https://doi.org/10.17559/TV-20140724220401

[8] Bako, B.; Božek, P. Trends in simulation and planning of manufacturing companies. // Procedia Engineering. 149, (2016), pp. 571-575. https://doi.org/10.1016/.proeng.2016.06.707

[9] Božek, P. Control of a robotic arm on the principle of separate decision of an inertial navigation system. // Applied Mechanics and Materials. 611, (2014), pp. 60-66. https://doi.org/10.4028/www.scientific.net/AMM.611.60

[10] Božek, P.; Pokorný, P. Automatic system for object recognition in robotic production line for automotive industry. // Mechatronics 2013: Recent Technological and Scientific Advances, (2014), pp. 653-662.

[11] Adhesive information, http://www.forbo.com

[12] Information about ABB IRB 1600, http://www.abb.com.

[13] Uses pneumatic components, http://www.smc.eu.

[14] Information about painting gun RA5, http://www.krautzberger.com 


\section{Authors' addresses}

Marek Sukop, Assoc. Prof., PhD.

Technical University of Kosice, Faculty of Mechanical Engineering, Department of Robotics

Park Komenského 8, 04200 Košice, Slovakia

marek.sukop@tuke.sk

\section{Mikuláš Hajduk, Prof. Eng. PhD.}

Technical University of Kosice, Faculty of Mechanical Engineering, Department of Robotics

Park Komenského 8, 04200 Košice, Slovakia

mikulas.hajduk@tuke.sk

Ján Semjon, Assoc. Prof., PhD

Technical University of Kosice, Faculty of Mechanical

Engineering, Department of Robotics

Park Komenského 8, 04200 Košice, Slovakia

jan.semjon@tuke.sk

\section{Jozef Varga, Eng. PhD.}

Technical University of Kosice, Faculty of Mechanical Engineering, Department of Robotics

Park Komenského 8, 04200 Košice, Slovakia

jozef.varga.2@tuke.sk

Rudolf Jánoš, Eng. PhD.

Technical University of Kosice, Faculty of Mechanical Engineering, Department of Robotics

Park Komenského 8, 04200 Košice, Slovakia rudolf.janos@tuke.sk

\section{Marek Vagaš, Eng. PhD.}

Technical University of Kosice, Faculty of Mechanica Engineering, Department of Robotics

Park Komenského 8, 04200 Košice, Slovakia

marek.vagas@tuke.sk

\section{Martin Bezák, Eng.}

VIPO, a.s.

Gen. Svobodu 1069/4, 95801 Partizánske, Slovakia

Park Komenského 8, 04200 Košice, Slovakia

bezak@vipo.sk

Ivan Virgala, Assoc. Prof., PhD.

Technical University of Kosice, Faculty of Mechanical

Engineering, Department of Mechatronics

Park Komenského 8, 04200 Košice, Slovakia

marek.sukop@tuke.sk 